\title{
An Assessment of Nigerians Perception towards Chinese Foreign Direct Investments and Its Acceptability in Nigeria
}

\author{
Sunday Adiyoh Imanche ${ }^{1,2 *}$, Tian Ze'1, Moses Chia Ayom³ ${ }^{3}$, S. G. Dalibi ${ }^{1}$ \\ ${ }^{1}$ Business School of Hohai University, Nanjing, China \\ ${ }^{2}$ Department of Economics, Federal University, Wukari, Nigeria \\ ${ }^{3}$ Heritage Africa-China Research Institute, Abuja, Nigeria \\ Email: ^imanchesunny@gmail.com
}

How to cite this paper: Imanche, S. A., Ze, T., Ayom, M. C., \& Dalibi, S. G. (2021). An Assessment of Nigerians Perception towards Chinese Foreign Direct Investments and Its Acceptability in Nigeria. Open Journal of Business and Management, 9, 1151-1168. https://doi.org/10.4236/ojbm.2021.93062

Received: March 15, 2021

Accepted: May 14, 2021

Published: May 17, 2021

Copyright $\odot 2021$ by author(s) and Scientific Research Publishing Inc. This work is licensed under the Creative Commons Attribution International License (CC BY 4.0).

http://creativecommons.org/licenses/by/4.0/ (c) (i) Open Access

\begin{abstract}
Perceptions play a critical role in international affairs. Politicians must be able to consider and forecast both challenges and opportunities. Public opinion has the power to change the course of politics. As the world becomes more interconnected, it's critical to comprehend how China is perceived and how this affects China's global effect. Although it only makes up a small part of overall Chinese OFDI, this investment class has recently drawn interest because of its sectoral and geographic diversification. Nigeria has been one of China's top 40 trading partners for more than five decades. For some time, it has been the leading African investment destination for Chinese investment in the continent. The pursuit of multilateral agreements has a significant effect on how countries engage in the political and economic realm. This study used both quantitative and qualitative methods. The study adopted simple random sampling techniques to allow for equal and unbiased respondents' participation in the primary data collection. The response scale was base on a 1 - 5 points Likert scale. Secondary data was sourced from archival materials, published books or scholarly works, the internet, international organization official documents, journals, press releases, newspapers. The overall research accepts the study's alternative hypothesis, which shows that perhaps the ten outlined perceptions of Nigerians towards Chinese FDIs and its acceptability are heavily influenced by the success of FDI by Chinese investors and businesses in Nigeria's market climate. The importance and positive outcomes of such FDI are heavily reliant on Nigerian perceptions of Chinese FDI and their acceptability and the investment target region.
\end{abstract}

\section{Keywords}

China, Perception, FDI, Acceptability, Nigeria 


\section{Introduction}

In international relations, perceptions play a crucial role. Politicians must be able to identify and predict risks as well as opportunities. The tide of politics can be sway by public sentiment. As the world becomes more interconnected, it's crucial to understand how China is viewed and how that affects China's global impact. The controversy about China's foreign direct investment in Africa has erupted: Even though Africa only accounts for a small percentage of total Chinese outward Foreign Direct Investment (OFDI) in terms of volume, it is a growing market (both inflows and stocks). These investments have recently gained a lot of attention due to their sectoral and geographical diversification and their economic and geopolitical implications.

The Sino-Nigeria bilateral relations are over five decades, Nigeria has been ranked high among China's top 40 trading partners globally and its most significant investment destination in Africa. The quest for global multilateralism plays a considerable part in shaping political and economic relationships among nations of the world. Such factors are summarized to these main factors; seek natural resources and export markets (Asiedu et al., 2015; Asiedu, 2002; Jakobson, 2009). China's trade with Africa has reached $\$ 208.7$ billion, with Foreign Direct Investment (FDI) totaling $\$ 49.1$ billion; amid its fragile economy in recent years, Nigeria remains one of China's most prominent investment destinations in Africa. The size of trade between Nigeria and China in 2019 was more than \$19 billion, equaling 1900 times the trade volume during 1971 when diplomatic relations were established (Odoh, 2021).

Despite the adverse effects of Covid-19, the amount of bilateral trade increased by 0.7 percent year on year from January to October 2020, which was 14 percent higher than the growth rate of trade between China and Africa as a whole. To become China's second-largest trade partner and largest export market in Africa, Nigeria surpassed Angola and South Africa, respectively. At the same time, China's leading investment destination in Africa is Nigeria. Local Chinese are moving to support their brothers and sisters in Nigeria, with a total amount of $\$ 1.2$ million in materials and funds donated by local Chinese companies and nationals. At the same time, China's leading investment destination in Africa is Nigeria (Lan, 2015; Martyn, 2019).

Consequently, perception and acceptability play a vital role in the smooth running of businesses from the host nations to the host nations (Cooke, 2012; Harris et al., 2010; Koenig-Archibugi, 2004). Nigerians' positive perception of China has created opportunities for Chinese investments to thrive in Nigeria. Many Chinese companies have been attracted to invest and run their enterprises by the Ogun-Guangdong Free Trade Zone and Lekki Free Zone (Brautigam, Deborah, Farole, Thomas, \& Tang, 2010; Hannafi Ibrahim et al., 2020; Zeng, 2016). Infrastructure projects jointly constructed by the two countries can be seen everywhere in Nigeria, such as bridges, ports, and airport terminals (Akpoilih \& Farayibi, 2017; Babatunde \& Low, 2013; Ighodaro, 2018). China is 
ready to further joint efforts with Nigeria to strengthen bilateral relations and strengthen cooperation on the Belt and the Road Initiative. China also takes a close look at Nigeria's development and strives to reach its full potential while helping Nigeria's participation in the ongoing Belt and Road initiative (Abutu, 2012; Jackson et al., 2020; Onomake-McShane, 2019). Also, to accelerate the development of critical projects to help Nigeria accelerate industrialization, explore cooperation in the green economy and digital economy. Also, to expand military and security cooperation for a win-win relationship, China pursues security cooperation (Bala, 2012; Miao et al., 2020; Odoh, 2021; Oyeranti et al., 2010).

However, this research aims to assess perception towards Chinese Foreign Direct Investments and its acceptability in Nigeria. Most empirical research has focused on the fact that there is a pattern and that it has benefits. Focusing on Nigeria's economic factors, this paper will absorb these major trade and political determining variables: FDIs from China prompt fast delivery of infrastructural construction projects in Nigeria; China-Nigeria relationship is mutually beneficial; FDI from China enables the provision of Modern transportation infrastructure; FDIs from China generates positive spill-overs; FDI from China Improves delivery of Technology, Goods and Services to Nigerians; FDIs from China affect the economic growth of Nigeria (GDP, FOREX, Inflation, etc.); FDIs from China positively impact various economic sectors of Nigeria; FDIs from China were fostering linkages with local firms; Chinese Investments improve the social living standard of Nigerians and the business environment; FDI from China Improves Nigerians' social amenities and lifestyles.

It will also be essential to highlight the particular type of FDI that generates a broad range of opinions, from the growth-enhancing essence of Chinese investment to a more cynical, neo-colonialist interpretation. The continuing tensions between the United States and China have polarized views on Chinese foreign direct investment in Africa. We provide a causal evidence-based study of the importance of FDI from China, as a huge trading and production center, where China is pouring in both domestically and to countries in Africa and on the African continent, and around the rest of the world. The relation between Nigeria and China has withstood the test of time, removing disturbances, and has become a model for international relations and its South-South cooperation. This study seeks to assess Nigerians' perception towards Chinese Foreign Direct Investments and their acceptability in Nigeria.

The remaining parts of this article will be divided into four parts; with the literature review imminent, the third section will focus on scientific methods. In contrast, the fourth section will relay the empirical study's findings, and the conclusions will be outlined finally in the last section.

\section{Literature Review}

Several studies have been carried out about factors responsible for foreign na- 
tionals' perception and acceptability towards each other. Many years ago, the relationship between China and Africa changed from routine to significant and critical for both parties (Alden \& Jiang, 2019; Taylor, 1998). It's a special relationship formed by and passed on from generation to generation (Kalu \& Aniche, 2020; Onjala, 2008; Strauss, 2009). Nigeria and China have some things in common. Both Nigeria and China have celebrated anniversaries of their national day on similar dates before, with similar events that are common to both have been held in the past. Another illustration is that both countries defended their independence and became allies in suffering together, achieved mutual well-being, and established a brotherly bond. Cooperation in growth is when all sides progress and become good partners to achieve a win-win situation and move forward successfully (Bednarz et al., 2017; McDowell, 2012; Udeala, 2010). Nigeria-China ties have stood the test of time, overcoming adversity and being a model for foreign relations and South-South cooperation (Iyabo, 2018; Morrison et al., 2008; Shinn, 2017; Soludo, 2018).

Nigeria and China have both accomplished a great deal in infrastructure, investments, oil, culture, education, and industry (Odutola, 2019; Utomi, 2008; Zeng, 2016; Zhao, 2014). And, while China has a lot to give, Nigeria would need all the help it can get, keeping in mind that this will be a win-win situation for both parties (Imanche et al., 2020). Nigeria is China's most important project-contracting market, most significant export market, second-largest trading partner, and major investment destination in Africa. The bilateral trade volume in 2019 was $\$ 19.27$ billion, up 26.3 percent year on year, and ranked first among China's top 40 trading partners (Chen, 2016; Mohammed, 2019; Quadri, 2020; Taylor, 2010).

China's direct investment stock in Africa topped US $\$ 49.1$ billion in 2019, nearly a 100 -fold increase since 2000; China-Africa trade topped the US \$208.7 billion, a 20 -fold increase since 2000. China has been Africa's leading trading partner for 11 years in a row, and for years before that, it has contributed more than $20 \%$ to Africa's growth. A growing trend in other fields, particularly in the field of technology, cooperation between people, and the interaction between people are furthering advancement in various spheres, such as culture, health, and education are affecting (Odutola, 2019; Ogunsina, 2019; Ojeme, 2019; Shinn, 2019).

In Nigeria, there are several China-Nigeria projects that are either ongoing or that have been completed across the country, namely: The Abuja-Kaduna Railway, the Lagos-Ibadan Railway, New airport terminals of Abuja, Port Harcourt and Kano, Zungeru 700-Megawatt Hydro-power plant, Ogun-Guangdong Free Trade Zone, the Lekki Free Trade Zone, the offshore Patrol Vessels (OPVs) as well as the Agricultural Science and Technology Demonstration Parks among others (Bolomope et al., 2020; Seriki, 2020).

Many emerging markets welcome economic relations with China, but there are some concerns about Beijing's impact (Feigenbaum, 2020; Goulard, 2020; Li, 
2021). Investments from China in contrast, on the other hand, are only tangentially linked to perceptions of China in the countries surveyed. Despite investing hundreds of billions of dollars in the Belt and Road Initiative, especially in emerging economies, the size of Beijing-funded capital investments or construction contracts in a country is only weakly linked to that country's overall China views. Since 2005, China has given Indonesia more than $\$ 47$ billion in capital investment and construction projects, but its attitudes toward China are evenly divided, with 36 percent favorable and 36 percent unfavorable. On the other hand, China has sent $\$ 44$ billion to Nigeria in the same time frame, and 70 percent of Nigerians think highly of China (Silver et al., 2019).

Nigerians have the second-most favorable view of China after Russians (Brautigam, 2020; Fairchild, 2020). Nigeria is instead of viewing China's rising economy as a positive for their country than negatively (Omotoso et al., 2020; Pay \& Nwosu, 2020; Yusuff et al., 2020). That 55\% think a robust Chinese economy is advantageous, while $30 \%$ believe it is a problem for the nation (Banwo, 2020; Kolodko, 2020; Toye, 2021). Most people in Africa and Latin America believe China's rising economy is beneficial to their countries (Borquez \& Bravo, 2020; Gouvea et al., 2020; Oliveira \& Myers, 2020; Singh, 2020; Stallings, 2020). China's investment is seen as a positive in countries outside of the Asia-Pacific region. In Nigeria, Tunisia, Lebanon, Mexico, Israel, Kenya, South Africa, and Brazil, about six out of ten people welcome Chinese investment. Turkey and Argentina are more ambiguous, with no strong consensus on whether Chinese investment is beneficial or harmful to their countries (Silver et al., 2019). Figure 1 shows the general views of Nigerians about Chinese in Nigeria.

Figure 1 shows the results of a Pew Research Center poll conducted in 2019, which found that a large majority of Nigerians hold favorable views of China on a variety of economic issues: 83 percent believe China's growing economy is good for their country, while a similar share (82 percent) believe Chinese investment is good because it creates jobs in their country. In both cases, these percentages were the highest among the 11 emerging economies the Center surveyed in 2019 (Silver et al., 2019).

However, studies show that political factors are also significant determinants (Baydoun et al., 2021). FDIs from China prompt fast delivery of infrastructural

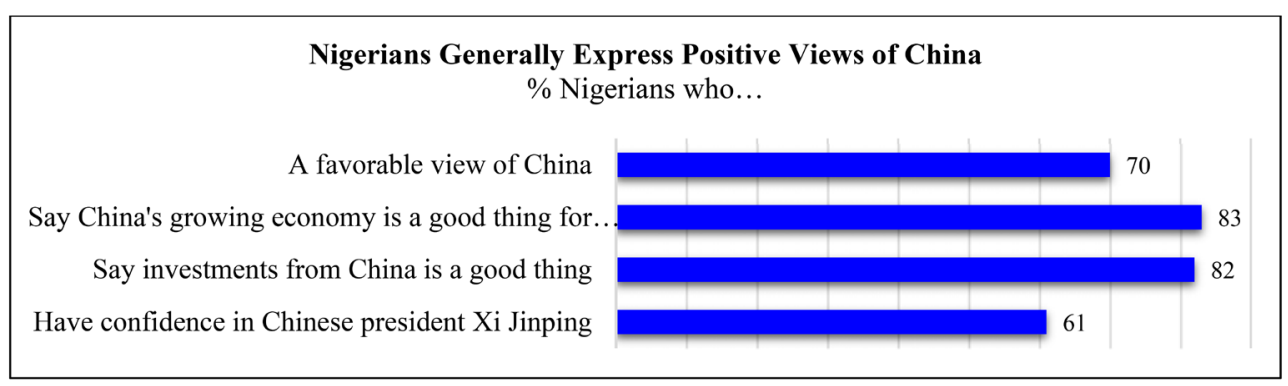

Source: Author 2021 based on Spring 2019 global attitude survey as cited in (Silver et al., 2019).

Figure 1. Nigerians general views of China. 
construction projects in Nigeria. Such is the research argument as each scholar tries to justify peculiar economic situations about what is acceptable and what is not acceptable. This paper will borrow most of these economic and political factors in evaluating the determinant of China-Nigeria trade with much emphasis on Nigeria's economic factor, which these authors have overlooked.

\section{Methodology}

This study used quantitative method by adopting a structured questionnaire survey. The questionnaire is divided into respondents profile and the $11 \mathrm{nr}$ perception of Nigerians towards Chinese FDIs and its acceptability. The Research Target Population was the Nigerian Professionals from various disciplines (Economists, Technocrats, Diplomats, Trade and Investment Analysts, Government Representatives, Academic Scholars, etc.) with good knowledge about the Chinese FDI and international relations between China and Nigeria. These professionals cut across the public and the private sectors. The study adopted simple random sampling techniques to allow for equal and unbiased participation of respondents. The total number of samples in the population was based on Krejcie and Morgan (Krejcie \& Morgan, 1970) sampling technique. The response scale was based on a 5-point Likert scale using scale options to provide a response range such as Strongly Agree $=5$; Agreed $=4$; Neutral/Undecided $=3$; Disagree $=2$; Strongly Disagree $=1$

\subsection{Data Analyses}

\section{Responsive Questionnaires}

The respondent's responses from the fieldwork were shown in the table and figures below. Table 1 shows the questionnaire responses.

Table 1 clearly shows that from the total of 750 questionnaires distributed, only 410 questionnaires were responsive, representing 55\%, whereas 340 questionnaires were non-responsive, representing $45 \%$. This shows that the total response from the Questionnaires was fair based on $64 \%$ retrieved and analyzed. However, the questionnaires were distributed manually and electronically, as shown in Table 2.

Table 2 clearly shows that from the total of 750 questionnaires distributed, 477 were circulated electronically, of which 263 questionnaires representing 55.1\% were retrieved; $44.9 \%$ were not. Also, 273 questionnaires were distributed manually,

Table 1. Questionnaire's responses.

\begin{tabular}{ccc}
\hline Questionnaires Distributed & Frequency & Percentage \\
\hline Returned & 410 & $54.7 \%$ \\
Non-Returned & 340 & $45.3 \%$ \\
TOTAL & 750 & $100 \%$ \\
\hline
\end{tabular}

Source: Author's calculation, 2021. 
of which 147 questionnaires representing 53.8\% were retrieved manually; $46.2 \%$ were not.

\subsection{Demography of Respondents}

The analyses below show the research respondents by their sectors.

Table 3 clearly shows that the private sector respondents constitute 63\%; respondents from the public sector include $31 \%$ while those in the other (semi-public sector or semi-private sector) comprise the remaining $6 \%$ of the total responses retrieved and analyzed. It can also be deduced that the respondents with Bachelor Degree constitute 51\%; respondents with Masters' Degree constitute 30\%; respondents with Ph.D. or Doctorate Degree constitute 9\%; while respondents with other qualifications (such as professional certificates,

Table 2. Manually and electronically questionnaires distribution and responses.

\begin{tabular}{ccccc}
\hline \multirow{2}{*}{ Questionnaires Distributed } & \multicolumn{2}{c}{$\begin{array}{c}\text { Electronically Distributed } \\
\text { Questionnaires }\end{array}$} & \multicolumn{2}{c}{$\begin{array}{c}\text { Manually Distributed } \\
\text { Questionnaires }\end{array}$} \\
\cline { 2 - 5 } & Frequency & Percentage & Frequency & Percentage \\
\hline Returned & 263 & $55.1 \%$ & 147 & $53.8 \%$ \\
Non-Returned & 214 & $44.9 \%$ & 126 & $46.2 \%$ \\
TOTAL & 477 & $100 \%$ & 273 & $100 \%$ \\
\hline
\end{tabular}

Source: Author's calculation, 2021.

Table 3. Respondents organizations by sector.

\begin{tabular}{ccc}
\hline Respondents by Sector & Frequency & Percentage \\
\hline Private Sector & 258 & $62.9 \%$ \\
Public Sector & 127 & $31.0 \%$ \\
Other & 25 & $6.1 \%$ \\
TOTAL & 410 & $100 \%$ \\
\hline Educational Qualification of Respondents & Frequency & Percentage \\
\hline Doctorate & 36 & $8.8 \%$ \\
Masters' Degree & 122 & $29.8 \%$ \\
Bachelor Degree /HND & 211 & $51.5 \%$ \\
Others & 41 & $10.0 \%$ \\
TOTAL & 410 & $100 \%$ \\
\hline Respondents Years of Experience & Frequency & Percentage \\
\hline 1 - 10 years & 182 & $44.4 \%$ \\
10 - 20 years & 147 & $35.9 \%$ \\
Above 20years & 81 & $19.8 \%$ \\
TOTAL & 410 & $100 \%$ \\
\hline
\end{tabular}

Source: Author's calculation, 2021. 
technical certificates and or diploma) comprise $10 \%$. As such, the research respondents with Bachelor have the highest. In contrast, those with postgraduate educational qualifications (Master's degree and Doctorate) have 158 responses representing $39 \%$ of the total responses, which is less than that of Bachelor degree holders. Table 3 clearly indicates that respondents with $1-10$ years of experience constitute $44 \%$; respondents with 10 - 20 years of experience constitute $36 \%$; respondents with above 20 years of experience constitute $20 \%$ of the total responses. The research respondents with $1-10$ years of working experience have almost $44 \%$ of this research work's total responses.

\subsection{Analyses of Perception of Nigerian towards Chinese FDIs and its Acceptability}

Based on the data obtained from the retrieved questionnaires for this study, an analysis of Nigerian perceptions of Chinese FDIs and their acceptability. Table 4 summarizes the information.

Table 5 shows the assessments of Nigerian perception towards Chinese FDIs and its acceptability using the Mean Item Score Model to ascertain the performance rate.

Table 5 deduced that the perception of Nigerian towards Chinese FDIs and their acceptability varies accordingly. Three factors have an extremely high impact; four factors have a strong impact, while three factors have a moderate

Table 4. Perception of Nigerian towards Chinese FDIs and its Acceptability.

\begin{tabular}{|c|c|c|c|c|c|c|c|}
\hline S/N & $\begin{array}{l}\text { Perception of Nigerian towards Chinese FDIs and its } \\
\text { acceptability }\end{array}$ & $\begin{array}{c}\text { Strongly } \\
\text { Agree }=5\end{array}$ & $\begin{array}{l}\text { Agree } \\
=4\end{array}$ & $\begin{array}{c}\text { Neutral/ } \\
\text { Undecide } \\
\mathrm{d}=3\end{array}$ & $\begin{array}{l}\text { Dis-Agree } \\
\quad=2\end{array}$ & $\begin{array}{l}\text { Strongly } \\
\text { Dis-Agree } \\
\quad=1\end{array}$ & Total \\
\hline 1 & China-Nigeria relationship is mutually beneficial & 224 & 185 & 1 & 0 & 0 & 410 \\
\hline 2 & FDIs from China generates positive spillovers & 144 & 202 & 55 & 2 & 7 & 410 \\
\hline 3 & FDIs from China fostering linkages with local firms & 116 & 151 & 122 & 4 & 17 & 410 \\
\hline 4 & $\begin{array}{l}\text { FDIs from China positively impact various economic sectors of } \\
\text { Nigeria }\end{array}$ & 142 & 139 & 109 & 9 & 11 & 410 \\
\hline 5 & $\begin{array}{l}\text { FDIs from China affect the economic growth of Nigeria (GDP, } \\
\text { FOREX, Inflation, etc.) }\end{array}$ & 131 & 173 & 96 & 4 & 6 & 410 \\
\hline 7 & $\begin{array}{l}\text { FDI from China enables the provision of Modern } \\
\text { transportation infrastructure }\end{array}$ & 259 & 127 & 13 & 4 & 7 & 410 \\
\hline 8 & $\begin{array}{l}\text { FDI from China Improves delivery of Technology, Goods and } \\
\text { Services to Nigerians }\end{array}$ & 131 & 195 & 77 & 4 & 3 & 410 \\
\hline 9 & $\begin{array}{l}\text { FDIs from china prompt fast delivery of infrastructural } \\
\text { construction projects in Nigeria }\end{array}$ & 331 & 58 & 14 & 1 & 6 & 410 \\
\hline 10 & $\begin{array}{l}\text { FDI from China Improves social amenities and lifestyles of } \\
\text { Nigerians }\end{array}$ & 64 & 40 & 211 & 11 & 84 & 410 \\
\hline 11 & $\begin{array}{l}\text { Chinese Investments improve the social living standard of } \\
\text { Nigerians and the business environment }\end{array}$ & 84 & 50 & 209 & 7 & 60 & 410 \\
\hline
\end{tabular}

Source: Author's calculation, 2021. 
Table 5. Assessing Nigerian Perception towards Chinese FDIs and Its Acceptability using the Mean Item Score Model.

\begin{tabular}{|c|c|c|c|}
\hline $\mathrm{S} / \mathrm{N}$ & Perception of Nigerian towards Chinese FDIs and its acceptability & MIS & Remark \\
\hline 1 & China-Nigeria relationship is mutually beneficial & 4.54 & Strongly Agree \\
\hline 2 & FDIs from China generates positive spillovers & 4.16 & Agree \\
\hline 3 & FDIs from China fostering linkages with local firms & 3.84 & Agree \\
\hline 4 & FDIs from China positively impact various economic sectors of Nigeria & 3.96 & Agree \\
\hline 5 & FDIs from China affect the economic growth of Nigeria (GDP, FOREX, Inflation, etc.) & 4.02 & Agree \\
\hline 6 & FDI from China enables the provision of Modern transportation infrastructure & 4.53 & Strongly Agree \\
\hline 7 & FDI from China Improves delivery of Technology, Goods, and Services to Nigerians & 4.09 & Agree \\
\hline 8 & FDIs from china prompt fast delivery of infrastructural construction projects in Nigeria & 4.72 & Strongly Agree \\
\hline 9 & FDI from China Improves social amenities and lifestyles of Nigerians & 2.97 & Neutral/Undecided \\
\hline 10 & Chinese Investments improve the social living standard of Nigerians and the business environment & 3.22 & Neutral/Undecided \\
\hline
\end{tabular}

Source: Author's calculation, 2021.

effect on Nigerian perception towards Chinese FDIs and their acceptability.

The study deemed factors such as FDIs from China prompt fast delivery of infrastructural construction projects in Nigeria. China-Nigeria relationship is mutually beneficial. FDI from China enables the provision of Modern transportation infrastructure as having an extremely high impact on the perception of Nigerian towards Chinese FDIs and their acceptability. While other factors that substantially affect Nigerian perception towards Chinese FDIs and their acceptability were, FDIs from China generate positive spillovers. FDIs from China affect Nigeria's economic growth (GDP, FOREX, Inflation, etc.). FDIs from China positively impact various economic sectors of Nigeria FDIs from China fostering linkages with local firms. Also, Chinese Investments improve the social living standard of Nigerians and the business environment, and FDI from China Improves Nigerians' social amenities, and lifestyles were deemed to moderately impact Nigerian's perception towards Chinese FDIs and their acceptability.

Table 6 shows the assessments of Nigerian's perception towards Chinese FDIs and its acceptability using the Relative Importance Index (RII) Model to determine the socio-economic factors with the highest and lowest ranking.

Table 6 shows the following deductions were made:

The topmost highly ranked factors were FDIs from china prompt fast delivery of infrastructural construction projects in Nigeria $\left(1^{\text {st }}\right)$; China-Nigeria relationship is mutually beneficial $\left(2^{\text {nd }}\right)$; FDI from China enables the provision of Modern transportation infrastructure $\left(3^{\text {rd }}\right)$

The middle-ranked factors were FDIs from China generates positive spill-overs $\left(4^{\text {th }}\right)$; FDI from China Improves delivery of Technology, Goods, and Services to Nigerians $\left(5^{\text {th }}\right)$; FDIs from China affect the economic growth of Nigeria (GDP, FOREX, Inflation, etc.) $\left(6^{\text {th }}\right)$; FDIs from China positively impact various economic sectors of Nigeria $\left(7^{\text {th }}\right)$; FDIs from China fostering linkages with local firms $\left(8^{\text {th }}\right)$. 
Table 6. Assessing the perception of Nigerian towards Chinese FDIs and its acceptability using the relative importance index model.

\begin{tabular}{clcc}
\hline S/N & \multicolumn{1}{c}{ Perception of Nigerian towards Chinese FDIs and its acceptability } & RII & Ranking \\
\hline 1 & China-Nigeria relationship is mutually beneficial & 0.91 & $2^{\text {nd }}$ \\
2 & FDIs from China generates positive spillovers & 0.83 & $4^{\text {th }}$ \\
3 & FDIs from China fostering linkages with local firms & 0.77 & $8^{\text {th }}$ \\
4 & FDIs from China positively impact various economic sectors of Nigeria & 0.79 & $7^{\text {th }}$ \\
5 & FDIs from China affect the economic growth of Nigeria (GDP, FOREX, Inflation, etc.) & 0.80 & $6^{\text {th }}$ \\
7 & FDI from China enables the provision of Modern transportation infrastructure & 0.91 & $3^{\text {rd }}$ \\
8 & FDI from China Improves delivery of Technology, Goods and Services to Nigerians & 0.82 & $5^{\text {th }}$ \\
9 & FDIs from china prompt fast delivery of infrastructural construction projects in Nigeria & 0.94 & $1^{\text {st }}$ \\
10 & FDI from China Improves social amenities and lifestyles of Nigerians & 0.59 & $10^{\text {th }}$ \\
11 & Chinese Investments improve the social living standard of Nigerians and the business environment & 0.64 & $9^{\text {th }}$ \\
\hline
\end{tabular}

Source: Author's calculation, 2021.

Table 7. Testing of research hypotheses.

\begin{tabular}{|c|c|c|c|c|c|c|c|c|c|c|}
\hline $\begin{array}{l}\text { Perception of Nigeria } \\
\text { Towards Chinese FDI }\end{array}$ & Mean & $\begin{array}{l}\text { Standard } \\
\text { Deviation }\end{array}$ & $\begin{array}{l}\text { Standard } \\
\text { Error }\end{array}$ & $\mathbf{N}$ & DF & $\begin{array}{l}\text { Alpha (level of } \\
\text { Significance) }\end{array}$ & $\mathrm{P}$-value & T-cal & $\begin{array}{c}\text { Ttab } \\
0.05,10\end{array}$ & Significance \\
\hline $\begin{array}{l}10 \mathrm{nr} \text { factors for the Perception } \\
\text { of Nigerian towards Chinese } \\
\text { FDIs and its acceptability }\end{array}$ & 4.0 & 0.6 & 0.2 & 10 & 9 & 0.05 & 0 & 22.63 & 1.833 & yes \\
\hline
\end{tabular}

Source: Author's calculation, 2021.

The least ranked factors where Chinese Investments improve the social living standard of Nigerians and the business environment $\left(9^{\text {th }}\right)$ and FDI from China Improves Nigerians' social amenities and lifestyles $\left(10^{\text {th }}\right)$.

\subsection{Testing of Research Hypotheses}

The Significance of the research hypothesis regarding Nigerian perceptions of Chinese FDIs and their acceptability was tested using the MIS model's values in Table 6.

With 9 degrees of freedom (DF) and 5\% level of significance, the T-test calculated $(\mathrm{T}$-cal $=22.63)$ which is greater than $\mathrm{T}$-test tabulated $\left(\mathrm{T}-\mathrm{tab}_{0.05,9}=1.833\right)$; the significance level $(\mathrm{alpha}=0.05)$ is greater than the Probable value $(\mathrm{P}$-value $=$ 0.0000). As such, the null hypothesis was rejected, and the alternative hypothesis was accepted, which states, "Perception of Nigerian Towards Chinese FDIs and its Acceptability is significant." This Significance implies that the ten factors identified, assessed, and ranked were influential in Nigerian perception towards Chinese FDIs and their acceptability. This is so because for any FDI inflow to thrive, the conditions for how the host country are ready to perceive and accept the investor; this could be FDIs from China prompting fast delivery of infrastructural construction projects in Nigeria. And Nigerians seeing the Chi- 
na-Nigeria relationship is mutually beneficial, and also, seeing FDI from China as enabling the provision of Modern transportation infrastructure. Chinese Investments improve the social living standard of Nigerians and the business environment, and FDI from China Improves the social amenities and lifestyles of Nigerians. These were remarkable and a positive pointer to the mutual relationship between China and Nigeria.

\subsection{Correlations Analysis}

The relationship between China's benefits from investing in Nigeria and Nigeria's benefits from Chinese FDIs, as well as Nigerian perceptions of Chinese FDIs and their acceptability. The computations, are used to show which factor has a positive/negative/no relationship. The tables below show the performances' relationship based on the mean items' values in Table 8.

Table 8. Correlations between China's benefits of investing in Nigeria \& Nigeria's benefits from Chinese FDIs and the Perception of Nigerian towards Chinese FDIs and Its Acceptability

Correlations between China's benefits of investing in Nigeria \& Nigeria's benefits from Chinese FDIs and the Perception of Nigerian Towards Chinese FDIs And Its Acceptability
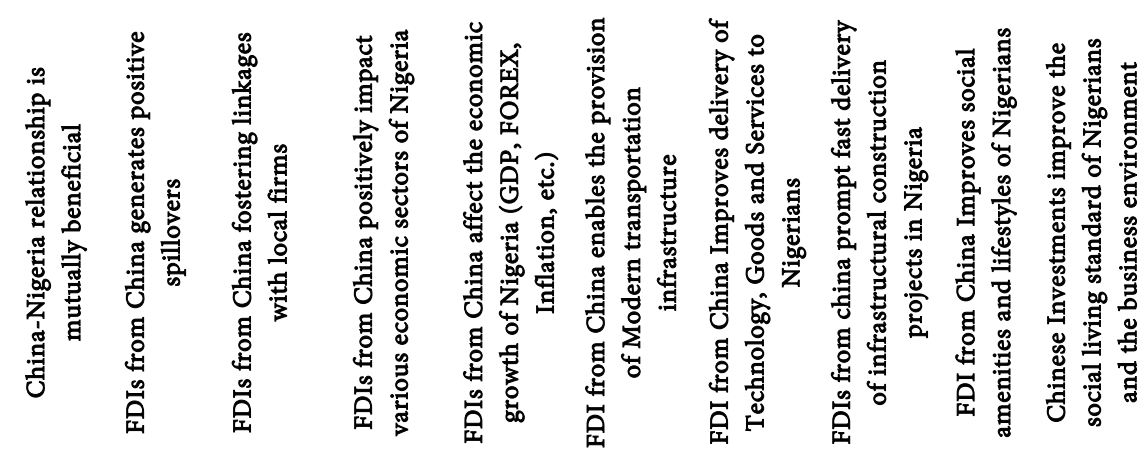

\begin{tabular}{|c|c|c|c|c|c|c|c|c|c|c|}
\hline $\begin{array}{c}\text { Nigeria offers Chinese companies a diverse } \\
\text { range of lucrative commercial and trade } \\
\text { opportunities }\end{array}$ & 0.81 & 0.54 & 0.40 & 0.60 & 0.49 & 0.95 & 0.47 & 1.00 & -0.18 & -0.02 \\
\hline $\begin{array}{c}\text { Access to Nigeria's Natural Resources for } \\
\text { Manufacturing }\end{array}$ & 0.90 & 0.67 & 0.49 & 0.68 & 0.60 & 0.99 & 0.60 & 0.98 & -0.24 & -0.07 \\
\hline Access to Nigeria's Markets & 0.84 & 0.58 & 0.43 & 0.63 & 0.53 & 0.97 & 0.52 & 1.00 & -0.20 & -0.03 \\
\hline Readily available human resources & 0.95 & 0.76 & 0.57 & 0.74 & 0.69 & 1.00 & 0.70 & 0.95 & -0.27 & -0.08 \\
\hline $\begin{array}{l}\text { Strengthening of Bilateral Relationship across } \\
\text { Political, Economic, Social, and other mutually } \\
\text { beneficial areas at the international stage (e.g., } \\
\text { UN, World Bank, WTO, IMF, WHO, etc.) }\end{array}$ & 0.91 & 0.71 & 0.56 & 0.74 & 0.67 & 0.99 & 0.65 & 0.97 & -0.18 & 0.00 \\
\hline $\begin{array}{l}\text { Chinese FDI provides counterpart funding in } \\
\text { major Infrastructural projects in Nigeria }\end{array}$ & 0.78 & 0.50 & 0.36 & 0.57 & 0.46 & 0.93 & 0.43 & 1.00 & -0.17 & -0.01 \\
\hline $\begin{array}{l}\text { Nigeria taps from the Technological Spillover } \\
\text { from Chinese expertise in various sectors }\end{array}$ & 0.94 & 0.73 & 0.54 & 0.72 & 0.66 & 1.00 & 0.66 & 0.96 & -0.26 & -0.08 \\
\hline Job creation in the Nigerian labor market & 0.82 & 0.55 & 0.40 & 0.61 & 0.50 & 0.95 & 0.48 & 1.00 & -0.18 & -0.02 \\
\hline $\begin{array}{l}\text { Nigeria enjoys Chinese confidence due to its } \\
\text { dynamic, open and competitive economy; } \\
\text { thereby attracting huge FDI in Africa }\end{array}$ & 0.73 & 0.43 & 0.31 & 0.53 & 0.40 & 0.90 & 0.36 & 0.99 & -0.14 & 0.01 \\
\hline
\end{tabular}

Source: Author's calculation, 2021 (from correlation computation results). 


\subsection{Discussion of Results}

Based on the above assessments, Nigerians' ten perceptions and acceptability toward Chinese FDIs were outlined using the Mean Item Score (MIS) model and the Relative Importance Index (RII) model to evaluate and comment on each of the perceptions and acceptability of Nigerians toward Chinese FDIs. These were based on how they affect the performances of FDI in Nigerian (by Chinese investors and Companies), indicating a remarkable impact from the FDI, as shown below.

From Tables 4-6, and Figure 2, it can be deduced that the impact of the perception of Nigerian towards Chinese FDIs and its acceptability varies accordingly. Perception such as FDIs from China prompt fast delivery of infrastructural construction projects in Nigeria, China-Nigeria relationship is mutually beneficial. FDI from China enables the provision of Modern transportation infrastructure to have an extremely high impact on Nigerian Perception towards Chinese FDIs and their acceptability. Other factors that have a substantial effect on the perception of Nigerian towards Chinese FDIs and their acceptability were FDIs from China generate positive spillovers. FDIs from China impact Nigeria's economic growth (GDP, FOREX, Inflation, etc.). FDIs from China positively impact various economic sectors of Nigeria FDIs from China fostering linkages with local firms. And lastly, Chinese Investments improve the social living standard

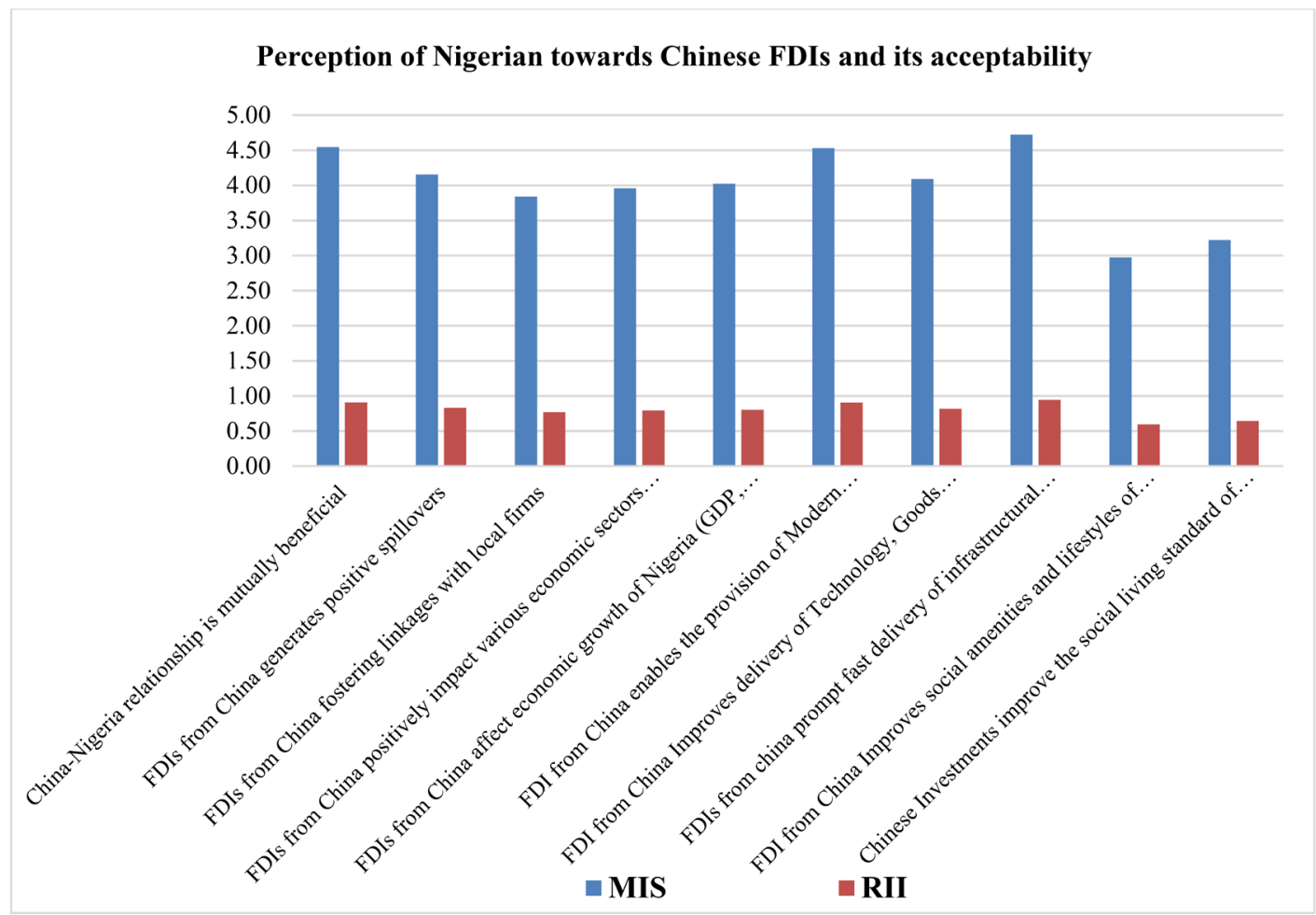

Source: Author's illustration, 2021.

Figure 2. Assessing the perception of Nigerian towards Chinese FDIs and its acceptability using the mean item score model and relative importance index model. 
of Nigerians and the business environment, and FDI from China Improves $\mathrm{Ni}$ gerians' social amenities. Lifestyles were considered to have a moderate perception of Nigerians towards Chinese FDIs Nigeria.

The topmost highly ranked perceptions were FDIs from China prompt fast delivery of infrastructural construction projects in Nigeria, China-Nigeria relationship is mutually beneficial, FDI from China enables the provision of Modern transportation infrastructure. The middle-ranked perceptions were FDIs from China generate positive spillovers, FDIs from China affect Nigeria's economic growth (GDP, FOREX, Inflation, etc.). FDIs from China positively impact various economic sectors of Nigeria FDIs from China fostering linkages with local firms. Whereas the least ranked perceptions where Chinese Investments improve the social living standard of Nigerians and the business environment, and FDI from China improve Nigerians' social amenities and lifestyles.

These ranking factors clearly show that Nigeria is in dire need of infrastructure. China has the technical and financial know-how to partner with Nigeria for both countries to benefit mutually. These infrastructures in the areas of modern transportation, roads, Ports, and so on further fostered the symbiotic relationship between China and Nigeria. Technology spill-overs are a significant factor that helps advance the host country's manufacturing prowess, thereby propelling economic growth. Chinese Investments improve Nigerians' social living standards due to the job creation aspect of the investments and the business environment, and FDI from China Improves the social amenities and lifestyles of Nigerians. These were the morale booster for Chinese investors. These variables were in tandem with the general quest for a mutual partnership that will benefit China and Nigeria both in the short-run and long-run, which paved the way for the population's ability to absorb and use new technology investors. The overall analysis accepts the alternative hypothesis for the study that shows that the ten outlined Perceptions of Nigerian Towards Chinese FDIs and its Acceptability, based significantly on the performance of FDI by Chinese investors and businesses in Nigeria's business environment. The value and positive results of such FDI hinges rely heavily on Nigerian perception towards Chinese FDIs and their acceptability and the investment target area.

\section{Conclusion}

The understanding and acceptance of foreign investors by host countries provide a favorable investment climate for them. Nigeria desperately needs infrastructure growth to realize its maximum economic potential. China has the technological and financial know-how to collaborate with Nigeria to help both countries. These infrastructures further enhanced the symbiotic relationship between China and Nigeria in modern transportation, highways, ports, and other areas. Technology spillovers are an essential factor in advancing the host country's manufacturing capabilities and, as a result, driving economic growth. Because of the job development aspect of Chinese investments and the business 
climate, Nigerians' social living standards rise, and FDI from China improves Nigerians' social facilities and lifestyles. For Chinese investors, this was a morale booster. These factors would help China and Nigeria progress and pave the way for citizens to embrace new technologies in the near term while favoring reciprocal cooperation in the long term. The importance and positive outcomes of such FDI rely heavily on Nigerian perceptions of Chinese FDI and their acceptability and the investment target region.

However, this study recommended that Chinese investors optimize Nigerians' positive perception towards them and eschew positive business ethics with Nigeria's stakeholders. Also, the Nigerian government should consolidate and strengthen the investment climate by repositioning investment platforms, thinning out investment barriers, bettering the current economic environment, and relaunching constructive initiatives. It is imperative to balance ties between China and Nigeria to ensure that Sino-Nigerian cooperation is sustained.

\section{Ethical Approval}

The authors received informed consent directly from the respondents of the questionnaire. They were informed of the voluntary nature of participation and all participants we assured of confidentiality of all information provided.

\section{Funding}

No funding was received for the publication for this paper.

\section{Conflicts of Interest}

The authors declare no conflicts of interest regarding the publication of this paper.

\section{References}

Abutu, L. O. (2012). GRIN-The Economic Relations between China and Nigeria.

Akpoilih, R. A., \& Farayibi, A. O. (2017). Determinants of Nigeria-China Bilateral Trade in Manufacturing Products. SSRN Electronic Journal. https://doi.org/10.2139/ssrn.2846061

Alden, C., \& Jiang, L. (2019). Brave New World: Debt, Industrialization and Security in China-Africa Relations. International Affairs, 95, 641-657. https://doi.org/10.1093/ia/iiz083

Asiedu, E. (2002). On the Determinants of Foreign Direct Investments to Developing Countries: Is Africa Different? World Development, 30, 107-119. https://doi.org/10.1016/S0305-750X(01)00100-0

Asiedu, E., Jin, Y., \& Kanyama, I. K. (2015). The Impact of HIV/AIDS on Foreign Direct Investment: Evidence from Sub-Saharan Africa. Journal of African Trade, 2, 1-17. https://doi.org/10.1016/j.joat.2015.01.001

Babatunde, O. K., \& Low, S. P. (2013). Chinese Construction Firms in the Nigerian Construction Industry. Habitat International, 40, 18-24. https://doi.org/10.1016/j.habitatint.2013.01.002 
Bala, E. N. (2012). Chinese-Nigeria Relations: Special Reference to Economic and Trade Relations.

Banwo, A. O. (2020). Entrepreneur Skills and Challenges: An Analogous Inquiry into Chinese and Nigerian Expertise.

Baydoun, N., Aziz Anwar, S., \& Sohail, M. S. (2021). The Perceived Determinants of Islamic Finance for China's Belt and Road Initiative. Journal of Transnational Management, 26, 18-38. https://doi.org/10.1080/15475778.2021.1880880

Bednarz, J., Bieliński, T., Nikodemska-Wollowik, A., \& Otukoya, A. (2017). Sources of the Competitive Advantage of Family Enterprises: An International Approach Focusing on China, Nigeria and Poland. Entrepreneurial Business and Economics Review, 5, 123. https://doi.org/10.15678/EBER.2017.050207

Bolomope, M. T., Awuah, K. G. B., Amidu, A.-R., \& Filippova, O. (2020). The Challenges of Access to Local Finance for PPP Infrastructure Project Delivery in Nigeria. Journal of Financial Management of Property and Construction. https://doi.org/10.1108/JFMPC-10-2019-0078

Borquez, A., \& Bravo, C. (2020). Who Are China's Strategic Economic Partners in South America? Asian Education and Development Studies.

https://doi.org/10.1108/AEDS-09-2019-0153

Brautigam, D. (2020). A Critical Look at Chinese "Debt-Trap Diplomacy": The Rise of a Meme. Area Development and Policy, 5, 1-14.

https://doi.org/10.1080/23792949.2019.1689828

Brautigam, D., Farole, T., \& Tang, X. (2010). China's Investment in African Special Economic Zones: Prospects, Challenges, and Opportunities. Poverty Reduction and Economic Management Network, No. 5, 1-6.

Chen, C.-K. (2016). China in Africa: A Threat to African Countries? The Strategic Review for Southern Africa, 38, 100.

Cooke, F. L. (2012). The Globalization of Chinese Telecom Corporations: Strategy, Challenges and HR Implications for the MNCs and Host Countries. The International Journal of Human Resource Management, 23, 1832-1852.

https://doi.org/10.1080/09585192.2011.579920

Fairchild, D. (2020). China in Africa: The Dragon in the Lion's Den.

Feigenbaum, E. A. (2020). Reluctant Stakeholder: Why China's Highly Strategic Brand of Revisionism Is More Challenging than Washington Thinks. In D. Ma (Ed.), China's Economic Arrival (pp. 113-130). Singapore: Palgrave Macmillan. https://doi.org/10.1007/978-981-15-2275-8 8

Goulard, S. (2020). The Impact of the US-China Trade War on the European Union. Global Journal of Emerging Market Economies, 12, 56-68. https://doi.org/10.1177/0974910119896642

Gouvea, R., Kapelianis, D., \& Li, S. (2020). Fostering intra-BRICS Trade and Investment: The Increasing Role of China in the Brazilian and South African Economies. Thunderbird International Business Review, 62, 17-26. https://doi.org/10.1002/tie.22098

Hannafi Ibrahim, K., Wulan Sari, D., \& Handoyo, R. (2020). Nigeria-China Bilateral Trade Relations: Is There Market Opportunities in China? Intermestic: Journal of International Studies, 4, 139-160. https://doi.org/10.24198/intermestic.v4n2.3

Harris, L., Russell-Bennett, R., Neale, L., \& Fullerton, S. (2010). The International Search for Ethics Norms: Which Consumer Behaviors Do Consumers Consider (Un)acceptable? Journal of Services Marketing, 24, 476-486.

Ighodaro, C. A. (2018). Foreign Direct Investment-Led Industrialisation in Nigeria: Les- 
sons from Chinese Industrialisation. Journal of Management and Development Dynamics, $28,69$.

Imanche, S. A., Tian, Z., Akintunde, T. Y., Orelaja, O. A., \& Tasinda, O. T. (2020). COVID-19, Sino-Nigeria Economic Relations and Consequences of Trade Deficits in Nigeria. Open Journal of Business and Management, 8, 2081-2092. https://doi.org/10.4236/ojbm.2020.85127

Iyabo, A. O. (2018). South-South Cooperation and the Prospects of Global Economic Balancing: A Study of Regulatory Frameworks of Nigeria-China Relations. PhD Thesis, Vanderbijlpark: North-West University (South Africa).

Jackson, T., Louw, L., \& Roshan Boojihawon, D. K. (2020). Chinese Organizations in Sub-Saharan Africa: New Dynamics, New Synergies. London: Routledge. https://doi.org/10.4324/9781315532097

Jakobson, L. (2009). China's Diplomacy toward Africa: Drivers and Constraints. International Relations of the Asia-Pacific, 9, 403-433. https://doi.org/10.1093/irap/lcp008

Kalu, K., \& Aniche, E. T. (2020). China-Africa Economic Relation: A Double-Edged Sword for Africa. African Journal of Economic and Sustainable Development, 7, 374-390. https://doi.org/10.1504/AJESD.2020.106827

Koenig-Archibugi, M. (2004). Transnational Corporations and Public Accountability. Government and Opposition, 39, 234-259. https://doi.org/10.1111/j.1477-7053.2004.00122.x

Kolodko, G. W. (2020). China and the Future of Globalization: The Political Economy of China's Rise. New York: Bloomsbury Publishing. https://doi.org/10.5040/9781788315487

Krejcie, R. V., \& Morgan, D. W. (1970). Determining Sample Size for Research Activities. Educational and Psychological Measurement, 30, 607-610. https://doi.org/10.1177/001316447003000308

Lan, S. (2015). Transnational Business and Family Strategies among Chinese/Nigerian Couples in Guangzhou and Lagos. Asian Anthropology, 14, 133-149. https://doi.org/10.1080/1683478X.2015.1051645

Li, Y. (2021). FDI Facilitating Sustainable Development In and Out of an Emerging Market: Is Foreign Participation a Necessary Condition for Emerging Market Firms to Catch Up Globally? In S. H. Park, M. A. Gonzalez-Perez, \& D. E. Floriani (Eds.), The Palgrave Handbook of Corporate Sustainability in the Digital Era (pp. 335-354). Springer. https://doi.org/10.1007/978-3-030-42412-1 17

Martyn, H. L. (2019). Looking for a Life: Nigerian Students Discuss Their Decisions to Study in China. Asian Social Science, 15, 30. https://doi.org/10.5539/ass.v15n6p30

McDowell, M. A. (2012). China in Nigeria. Naval War College Newport RI Joint Military Operations Dept.

Miao, M., Yushi, J., \& Borojo, D. G. (2020). The Impacts of China-Africa Economic Relation on Factor Productivity of African Countries. Economies, 8, 47. https://doi.org/10.3390/economies8020047

Mohammed, A. (2019). China-Nigeria Relations: An Opportunity or Opportunism?

Morrison, J. S., Cooke, J., Campos, I., Chege, M., Utomi, P., \& Vines, A. (2008). US and Chinese Engagement in Africa. Washington, DC: The CSIS Press.

Odoh, I. (2021). 50 Years Of Bilateral Ties: Nigeria Ranks First among China’s Top 40 Trading Partners. In Leadership Newspaper.

Odutola, A. (2019). How the Chinese Are Taking over Nigeria's Economy. Nairametrics. 
https://nairametrics.com/2019/11/28/how-the-chinese-are-taking-over-nigerias-econo $\underline{\mathrm{my} /}$

Ogunsina, B. (2019). Chinese Investments Shaping Belt and Road in Nigeria. Leadership Newspaper.

https:/leadership.ng/chinese-investments-shaping-belt-and-road-in-nigeria/

Ojeme, V. (2019). Nigeria, China Meet to Sustain Mutual Trade Relations. Vanguard News.

https://www.vanguardngr.com/2019/07/nigeria-china-meet-to-sustain-mutual-trade-re lations/

Oliveira, G. L. T., \& Myers, M. (2020). The Tenuous Co-Production of China's Belt and Road Initiative in Brazil and Latin America. Journal of Contemporary China, 1-19. https://doi.org/10.1080/10670564.2020.1827358

Omotoso, F., Kuti, G., \& Oladeji, I. O. O. (2020). Assessment of the (Inter) Dependency of Economic Relations between Nigeria and China: 1999-2019. Assessment, 7, No. 2. https://doi.org/10.17160/josha.7.2.639

Onjala, J. (2008). A Scoping Study on China-Africa Economic Relations: The Case of Kenya.

Onomake-McShane, U. E. O. (2019). Emerging Ties-Nigerian Entrepreneurs and Chinese Business Associates. Journal of Business Anthropology, 8, 167-184. https://doi.org/10.22439/jba.v8i2.5847

Oyeranti, O. A., Babatunde, M. A., \& Ogunkola, E. O. (2010). The Impact of China-Africa Investment Relations: The Case of Nigeria. AERC Collaborative China-Africa Project, 8 .

Pay, V. N., \& Nwosu, E. (2020). China’s Engagement with Africa: Promoting Rentierism? A Case Study of Sino-Nigerian Economic Relations. Asian Affairs, 51, 347-364. https://doi.org/10.1080/03068374.2020.1762358

Quadri, L. A. (2020). ONE BELT ONE ROAD: Should Nigeria Sieve the Chinese Benevolence, or Accept It as a Free Lunch? Akdeniz Havzası ve Afrika Medeniyetleri Dergisi, 2, 43-77.

Seriki, O. O. (2020). Looking through the African Lenses: A Critical Exploration of the CSR Activities of Chinese International Construction Companies (CICCs) in Africa. International Journal of Corporate Social Responsibility, 5, 1-9.

https://doi.org/10.1186/s40991-020-00055-1

Shinn, D. (2017). Deciphering Chinese Investment in Nigeria. China-US Focus. https://www.chinausfocus.com/finance-economy/deciphering-chinese-investment-in-n igeria

Shinn, D. H. (2019). China-Africa Ties in Historical Context. In A. Oqubay, \& J. Y. Lin (Eds.), China-Africa and an Economic Transformation (pp. 61-83). Oxford: Oxford University Press. https://doi.org/10.1093/oso/9780198830504.003.0004

Silver, L., Devlin, K., \& Huang, C. (2019). How People around the World View China. Pew Research Center's Global Attitudes Project. https://www.pewresearch.org/global/2019/12/05/attitudes-toward-china-2019/

Singh, A. (2020). The Myth of "Debt-Trap Diplomacy" and Realities of Chinese Development Finance. Third World Quarterly, 42, 239-253. https://doi.org/10.1080/01436597.2020.1807318

Soludo, C. (2018). This Day (Nigeria)-AAGM: Political Economy of Sustainable Democracy in Nigeria (2). 
https://muhaz.org/-this-day-nigeria-aagm-political-economy-of-sustainable-democr.ht ml?page $=6$

Stallings, B. (2020). Dependency in the Twenty-First Century?: The Political Economy of China-Latin America Relations. Cambridge: Cambridge University Press. https://doi.org/10.1017/9781108875141

Strauss, J. C. (2009). The Past in the Present: Historical and Rhetorical Lineages in China's Relations with Africa. The China Quarterly, 2009, 777-795. https://doi.org/10.1017/S0305741009990208

Taylor, I. (1998). China's Foreign Policy towards Africa in the 1990s. The Journal of Modern African Studies, 36, 443-460. https://doi.org/10.1017/S0022278X98002857

Taylor, I. (2010). The Forum on China-Africa Cooperation (FOCAC). London: Routledge. https://doi.org/10.4324/9780203835005

Toye, A. O. (2021). China-Africa Relations: The Northern Nigerian Textile Industry. PhD Thesis, Orange, CA: Chapman University.

Udeala, S. O. (2010). Nigeria-China Economic Relations under the South-South Cooperation. African Journal of International Affairs, 13, 61-88.

Utomi, P. (2008). 3 China and Nigeria.

Yusuff, S., Adekanye, T., \& Babalola, O. (2020). International Trade and its Effect on Economic Growth in Nigeria (1986-2017). American Journal of Economics, 4, 70-85.

Zeng, D. Z. (2016). Global Experiences of Special Economic Zones with Focus on China and Africa: Policy Insights. Journal of International Commerce, Economics and Policy, 7, 1650018. https://doi.org/10.1142/S1793993316500186

Zhao, S. (2014). A Neo-Colonialist Predator or Development Partner? China's Engagement and Rebalance in Africa. Journal of Contemporary China, 23, 1033-1052. https://doi.org/10.1080/10670564.2014.898893 